Katarzyna Mańko

https://doi.org/10.18778/8220-636-4.10

\title{
GDZIE DOTYKAĆ TEATRU?
}

Czarujemy się różnymi wizerunkami Łodzi: a to filmowej, a to przemysłów kreatywnych. Jedne z tych opowieści każą nam spojrzeć w przeszłość, by odzyskać tradycję, inne - tworzyć rzeczy nigdy tutaj niewidziane, ale opisane dokładnie na jednym z kanadyjskich uniwersytetów przez Richarda Floridę. Nikt nie mówi głośno, że jeśli Łódź jest silna na jakimś artystycznym polu, jest to właśnie teatr¹.

Jednak z roku na rok coraz śmielej można mówić o Łodzi jako o mieście teatralnym. Starsze festiwale rozwijają się i nierzadko zaskakują mieszkańców ciekawymi spektaklami z Polski, ale i z zagranicy. Na miejsce tych, których formuły się wyczerpują, szybko powstają nowe propozycje, propagujące odmienne idee i prekursorskie działania twórcze.

Festiwale teatralne promują Łódź, są jego wizytówką, pokazują niemały potencjał kultury miasta. Niektóre z nich mają dużą renomę i prestiż za granicą, inne są cenione w skali kraju, jeszcze inne liczą się w mieście ${ }^{2}$.

Przykładem tak rozkwitającego festiwalu jest z pewnością Dotknij teatru!, które to wydarzenie zaczęło swą karierę w roku 2010 od lokalnego uznania i aprobaty, a obecnie cieszy się ogólnopolską estymą i popularnością ${ }^{3}$.

1 Igor Rakowski-Kłos, Łódź przemysłów teatralnych, „Gazeta Wyborcza - Łódź” (16 marca 2012), s. 1,

2 Emilia Zimnica-Kuzioła, Festiwale teatralne w Eodzi-sezon 2011/2012, [w: ] Kultura jako czynnik rozwoju miasta na przykładzie Łodzi, red. Violetta Krawczyk-Wasilewska, Monika Kucner, Emilia Zimnica-Kuzioła, Wydawnictwo Uniwersytetu Łódzkiego, Łódź 2012, s. 134-135.

3 Dzisiejszy zasięg i wielość działań artystycznych podejmowanych w ramach akcji Dotknij teatru! można prześledzić na stronie internetowej przedsięwzięcia, http://dotknijteatru.pl/. Festiwal powstał dzięki kreatywności i doświadczeniu grona 
Dotknij teatru! w zamyśle organizatorów wcale nie miało być festiwalem. Idea jego powstania zrodziła się z chęci uczczenia Międzynarodowego Dnia Teatru i to właśnie w trakcie organizacji tej uroczystości ukształtowała się struktura i mechanizm realizacji tego zadania ${ }^{4}$. W różnorodnej gamie łódzkich festiwali długo nie było takiego, który angażowałby publiczność do jego współorganizowania:

wybitnych artystów, animatorów i pedagogów teatru. Trzeba przypomnieć raport organizatorów: „Grupę Inicjatywną, odpowiedzialną za przeprowadzenie tego karkołomnego pomysłu, utworzyli: Anna Ciszowska (Teatr Nowy im. K. Dejmka w Łodzi); Konrad Dworakowski (reżyser, dyrektor Teatru Pinokio w Łodzi); Joanna Ossowska (ówcześnie z-czyni dyrektora Teatru Pinokio w Łodzi); Tomasz Rodowicz (dyrektor Teatru Chorea); Marcin Brzozowski (dyrektor Teatru Szwalnia); Marian Glinkowski (ówcześnie dyrektor Łódzkich Spotkań Teatralnych i prezes Łódzkiego Oddziału Towarzystwa Kultury Teatralnej); Jadwiga Sącińska (teatrolożka, instruktorka teatralna, prezes honorowy łódzkiego Oddziału Okręgowego Towarzystwa Kultury Teatralnej); Krystyna Weinttrit (ówcześnie dyrektorka Centrum Kultury Młodych); Barbara Kurowska (z-czyni dyrektora Muzeum Kinematografii w Łodzi); Jolanta Sławińska (ówcześnie Teatr Muzyczny w Łodzi); Bożenna Krasnodębska (ówcześnie dyrektorka Wydziału Kultury Urzędu Miasta Łodzi); Małgorzata Gaduła-Zawratyńska (ówcześnie koordynatorka z Wydziału Kultury Urzędu Miasta Łodzi); Pola Amber i Julia Jakubowska z Teatru Chorea. W 2011 roku koordynacji Dotknij Teatru podjął się Teatr Nowy im. Kazimierza Dejmka, a jego dyrektor Zdzisław Jaskuła zagwarantował projektowi bazę organizacyjną i administracyjną. Rok później do akcji przystąpił Instytut Teatralny im. Zbigniewa Raszewskiego w Warszawie. Dzięki zaangażowaniu dyrektora Macieja Nowaka akcja uzyskała promocję ogólnopolską. Łódzkie założenia ideologiczne i programowe zaczęli wcielać w działanie partnerzy z całego kraju. I tak jest do dziś”, za: strona internetowa Teatru Nowego w Łodzi im. Kazimierza Dejmka, http: / / www.nowy.pl/item/teatrplus/article/DotknijTeatru/lang/pl (dostęp: 15.06.2016).

4 Na stronie Dotknij Teatru! w zakładce Inicjatywa czytamy: „Dzień Teatru domaga się wspólnoty. Jest idealnym pretekstem do jednoczenia sił twórczych, manifestowania różnorodności praktyk twórczych oraz znoszenia granic w przestrzeni i środowisku teatru. Projekt Dotknij Teatru wykorzystuje potencjał święta i kreuje warunki do przeżywania teatru według zasady: POZNAJ - DOŚWIADCZAJ - ZROZUM - POKOCHAJ. Oferuje widzom wielość wydarzeń: spektakle, warsztaty, czytania dramatów, akcje plenerowe, performance, wystawy, próby otwarte, projekcje, wykłady i koncerty. $\mathrm{W}$ efekcie promuje i popularyzuje sztukę teatru. Czyni ją dostępną i obecną, często w nietypowych przestrzeniach. Pozwala widzom odkrywać scenę »od kuchni« oraz tworzyć. Stawia pytania, prowokuje, zmusza do refleksji. A nade wszystko inicjuje spotkania ludzi teatru.

Inicjatywa ogólnopolskich obchodów Międzynarodowego Dnia Teatru pod szyldem Dotknij Teatru jest efektem połączenia oddolnej akcji Dotknij Teatru, powstałej w Łodzi, i warszawskiego projektu Instytutu Teatralnego pt. Chodź do teatru w 2012 roku. Zbieżność idei obu projektów pozwoliła na integrację działań na rzecz po- 
aż do czasu pojawienia się idei „dotykania teatru”. Akcja ta nie poprzestaje bowiem na propagowaniu konformistycznego oglądania spektakli przez widzów usadowionych w wygodnych fotelach, ale angażuje ich do twórczego działania. Oprócz szerokiej oferty warsztatów (od aktorskich po kostiumograficzne), można zgłosić własny projekt, przedstawić idee i pomysły wydarzeń, które zostaną rozpatrzone przez komisję. Szansę na „pokazanie się” szerszej publiczności ma każdy teatr publiczny, ale także dom kultury czy szkolne koło teatralne. Pomysł zorganizowania takiej akcji powstał podczas narady dotyczącej kreowania miejskiej oferty edukacji kulturalnej. Formułę i kształt przedstawiła Anna Ciszowska, reżyserka i animatorka teatru, a nazwę wymyśliła Barbara Kurowska, zastępca dyrektora Muzeum Kinematografii w Łodzi ${ }^{5}$. Zaufano przekonaniu, że teatr jest dla wszystkich i wszędzie. Nie trzeba szukać go tylko i wyłącznie w eleganckich salach teatralnych, bowiem można go „spotkać” na ulicy czy jadąc do pracy/szkoły tramwajem. Konrad Dworakowski, dyrektor łódzkiego Teatru Lalki i Aktora „Pinokio"6, przedstawiając program aktualnego festiwalu (w roku 2016), scharakteryzował jego nadrzędną ideę następująco:

Dotknij Teatru! to projekt, nad którego powstaniem - i nad tym, jak jest realizowany - zawisło słowo „spotkanie”. Z założenia miał być przedsięwzięciem egalitarnym, które zmienia pogląd na temat teatru, ale też zmienia rzeczywistość wokół. Miał trafić do społeczności, które są pozbawione dostępu do teatru i uruchomić myślenie o teatrze jako o czymś dostępnym i szczególnym w wymiarze doświadczenia ${ }^{7}$.

Krótko mówiąc: ten projekt zrodził się z marzenia. $\mathrm{Z}$ marzenia o tym, aby teatr w jednym czasie ogarnął swoim zasięgiem jak najwięcej publiczności z różnych środowisk - i chyba to się akurat udało ${ }^{8}$. W trakcie kolejnych edycji DT formułowane były następne zadania i cele - tak edukacyjne, jak i artystyczne.

zyskiwania partnerów. W efekcie akcja Dotknij Teatru rozszerzyła się na większość polskich województw", http://dotknijteatru.pl/inicjatywa/ (dostęp: 10.09.2016).

5 [Od lipca 2017 do lipca 2020 roku Barbara Kurowska pełniła funkcję dyrektora Muzeum Miasta Łodzi - przyp. red.]

6 [Konrad Dworakowski był dyrektorem Teatru Pinokio w latach 2009-2019; był także pomysłodawcą i dyrektorem artystycznym Międzynarodowego Festiwalu „Teatralna Karuzela" - przyp. red.]

7 Cyt.: [oma/agz/PAP] Dotknij Teatru! - obchody Międzynarodowego Dnia Teatru od 27 marca, [w: Kultura i sztuka po 1989 roku, http://dzieje.pl/kultura-i-sztuka/dotknijteatru-obchody-miedzynarodowego-dnia-teatru-od-27-marca (dostęp: 10.09.2016).

8 Monika Wąsik, Dotknij teatru - niech się święci!, http://teatralny.pl/rozmowy/ dotknij-teatru-niech-sie-swieci,1001.html (dostęp: 10.09.2016). 
Według Anny Ciszowskiej, dziś głównej koordynatorki festiwalu, powinno się go traktować przede wszystkim jako akcję czy ruch artystyczny na rzecz edukacji teatralnej, który jest w ciągłym procesie rozwoju.

Po siedmiu latach już wiemy, że efektem tego aktu artystycznego było ukształtowanie się dojrzałego festiwalu, ale celem było uświęcenie Dnia Teatru i od samego początku chcieliśmy, żeby ten dzień był pretekstem do wyjścia z teatrem na zewnątrz, do publiczności, w środowisko naturalne, żeby nie zachęcać widzów do przyjścia do teatru, a wyjść z teatrem do widzów. I w związku z tą ideą wychodzenia na zewnątrz i ujawnienia się, nastawienia się na dotykanie, poznawanie czy do prowokowania do bezpośredniego kontaktu $\mathrm{z}$ teatrem $\mathrm{w}$ bardzo różnych okolicznościach, czy to w Galerii Łódzkiej, na ulicach, nawet w tramwajach - dokonaliśmy pewnego bezpośredniego kontaktu teatralnego, spotkania, które jest nam - organizatorom bardzo bliskie9.

W deklaracjach organizatorów oraz w przyjętej strategii festiwalu idea brzmi pięknie. Jak to wygląda z perspektywy jego uczestników? Pierwsze Dotknij Teatru! rozpoczęło się 27 lutego 2010 roku wystawą jubileuszową Teatru Nowego w Galerii Łódzkiej. Swoją kulminację festiwal osiągnął 27 marca - kiedy to przypada Międzynarodowy Dzień Teatru - i na ten dzień zaplanowano korowód ulicą Piotrkowską, zwiedzanie Teatru Muzycznego, akcje plastyczne, wernisaże, spektakle, koncert ${ }^{10}$. Wręczono także nagrody łódzkim artystom związanym ze sztuką teatru. Jednym słowem - przez miesiąc kulturalna Łódź działała pod hasłem „dotykania teatru”. Akcja była rzeczywiście widoczna w wielu przestrzeniach miasta, począwszy od instytucji teatralnych, przez środki transportu, centra handlowe, a na Piotrkowskiej skończywszy. Łódź ogarnęła „teatromania”.

W czasie pierwszego festiwalu także i miłośnicy kina mogli znaleźć coś dla siebie: w Muzeum Kinematografii odbywały się projekcje filmów, których akcja rozgrywa się w teatrach. Pokazano też filmowe adaptacje trzech klasycznych sztuk: Wujaszka Wani Antona Czechowa, Hamleta Williama Shakespeare’a i Zemsty Aleksandra Fredry.

Organizatorzy festiwalu nawiązali do tradycji spotykania się łódzkiego środowiska teatralnego pod pomnikiem Leona Schillera. Odczytano tu, zwyczajowe od 1962 roku, uroczyste orędzie przygotowywane specjalnie na ten dzień przez

9 Rozmowa autorki artykułu z Panią Anną Ciszowską przeprowadzona 8 września 2016 roku.

10 Marcin Białczewski, Dotknij Teatru $w$ Łodzi - informacje, http://www. plasterlodzki.pl/teatr/aktualnoci-teatralne/819-dotknij-teatru-w-odzi-informacje (dostęp: 10.09.2016). 
wybitnych ludzi teatru ${ }^{11}$. Tym razem było to przesłanie napisane przez brytyjską aktorkę Judi Dench, której słowa: „Przedstawienia grane są wszędzie, nie tylko $\mathrm{w}$ miejscach przypisanych im tradycją" 12 zdawały się wyjątkowo dobrze harmonizować z ideą Dotknij teatru!

Doskonale pamiętam jedną z pierwszych edycji tego festiwalu; byłam wówczas w liceum, które zostało zaproszone do uczestniczenia w Korowodzie Teatralnym Ulicami Łodzi. Uczniowie klas teatralnych ze wszystkich łódzkich szkół mogli - w towarzystwie aktorów z Centrum Kultury Młodych - wyjść na ulicę i wspólnie świętować Dzień Teatru. Byliśmy wtedy widoczni i przyświecała nam jedna idea. Była to także okazja do zawarcia nowych znajomości z osobami, z którymi łączyła nas wspólna teatralna pasja.

Dziś trzeba jednak postawić trudne pytanie: czy przez siedem lat swego istnienia festiwal nie zagubił $\mathrm{w}$ jakimś stopniu deklarowanych założycielskich idei? Niepokoi też fakt, że czas trwania akcji z roku na rok ustawicznie się skraca - pierwsza edycja festiwalu trwała miesiąc, w roku 2013 było to dziesięć dni, a festiwal ubiegłoroczny zają̨ już zaledwie tydzień... ${ }^{13}$ Mam nieodparte wrażenie, że teatr, którego tak śmiało dotykaliśmy w pierwszych latach organizowania wydarzenia, skrył się w instytucjach kultury. Czyżby przez nagłą nieśmiałość? A może to wynik krępujących niedoskonałości, wynikających z braku czasu na odpowiednie przygotowanie przedstawienia? Nie każde wydarzenie $w$ programie festiwalu objęte jest dofinansowaniem. Informacja o przyznanych finansach także nie pojawia się od razu, tuż po ogłoszeniu wyników konkursu, więc czasem spektakl robiony jest w sposób nieco prowizoryczny i siłą rzeczy niedoskonały, brakuje środków (a przede wszystkim czasu) na jego spokojne dokończenie przed premierą. Anna Ciszowska, zapytana o powód „ukrycia się” akcji, wspomina o kłopotach, jakie niesie ze sobą nieprzewidywalność pogody.

11 Międzynarodowy Dzień Teatru został ustanowiony w 1961 roku w trakcie 9. światowego kongresu Międzynarodowego Instytutu Teatralnego (ITI) w Helsinkach. Ustalony dzień święta teatru - 27 marca - upamiętnia rocznicę otwarcia Teatru Narodów w Paryżu. Corocznie tego dnia, za pośrednictwem ponad stu narodowych ośrodków ITI, wygłaszane jest orędzie przygotowywane przez wybitnych ludzi teatru (wśród nich byli m.in. Jean Cocteau, Peter Brook, Vaclav Havel, Dario Fo, Krzysztof Warlikowski, Anatolij Wasiljew), a także przesłanie formułowane przez twórców z poszczególnych krajów.

12 Judi Dench, Orędzie na Międzynarodowy Dzień Teatru 2010, cyt. za stroną: http://www.teatrpolski.wroc.pl/archiwum/2009-2010/oredzie-na-miedzynarodowy-dzien-teatru-2010 (dostęp: 10.09.2016).

13 [Dotknij teatru! w latach 2017-2020 znów sukcesywnie się wydłużało - przyp. red.] 
Na przykład próby do Pasji w reżyserii Konrada Dworakowskiego, realizowane przez kilka środowisk teatralnych i przez Teatr Pinokio, odbywały się w zamkniętej przestrzeni ${ }^{14}$. Kilka dni przed premierą była przepiękna pogoda. Dzień przed premierą, w nocy, spadł śnieg i pogoda była fatalna. Zastanawialiśmy się co w tej sytuacji zrobić. W efekcie oczywiście artyści dokonali gestu wyjścia na zewnątrz, ale pracowali w warunkach ekstremalnych i kosztem zdrowia. $Z$ wieloma wydarzeniami mieliśmy podobny problem i to powoduje, że cofamy się z pleneru ${ }^{15}$.

Niewątpliwie, zarówno dla artystów, jak i dla widzów, bardziej komfortowe jest uczestniczenie w widowiskach, które odbywają się w bezpiecznych i przewidywalnych przestrzeniach, ale co uczynić wówczas z piękną, brawurową ideą „potykania się” przeciętnego łodzianina o teatr? Żeby ów teatr widz mógł rzeczywiście dotknąć i dać się w niego wciągnąć, musi teraz podjąć wszystkie tradycyjne czynności: sprawdzić repertuar, dojechać na miejsce prezentacji, wejść do budynku, nie wspominając już o dokonywaniu wcześniejszej rezerwacji miejsc. O ile podczas pierwszego Dotknij Teatru! jego uczestnicy byli doskonale widoczni (i słyszalni!) w Łodzi - przez swój udział w paradach i happeningach - o tyle teraz wydarzenia festiwalowe niewiele różnią się od tych składających się na bieżące sezony teatralne, a zatem nie wpływają na rytm życia miasta, sytuując się na (elitarnym) marginesie jego istnienia. Jak podkreśla Emilia Zimnica-Kuzioła:

Przedstawienia teatru ulicznego docierają do kilkutysięcznej widowni, publiczność potencjalna staje się publicznością realną. Dzięki takim inicjatywom rozszerza się audytorium teatru, w święcie tym uczestniczą dzieci wraz z rodzicami, widzowie reprezentujący różne środowiska, kategorie wiekowe. Teatr staje się czynnikiem integrującym zbiorowość i dostarczającym odbiorcom wielu wrażeń, emocji i refleksji. Dzięki temu, że „teatr wychodzi do widza”, dla wielu uczestników festiwalu jest to być może jedyna okazja zetknięcia się ze sztuką sceniczną ${ }^{16}$.

Prawdą jest, że spektakle prezentowane na DT w większości są darmowe, ale znaczną grupę potencjalnych widzów zniechęca do uczestniczenia we wspólnym świętowaniu już sama walka o miejsca, wyczekiwanie w długich i ciasnych kolejkach, by wejść na salę. Jest to dotkliwe szczególnie wówczas, kiedy nie jest się czynnym uczestnikiem takiej specyficznej formy teatru - nazwijmy go ogólnie - alternatywnego. Osoby, które są obeznane z teatralnym kontekstem i formą

14 Ale przedstawienie przewidziane było jako plenerowe.

15 Rozmowa autorki artykułu z Panią Anną Ciszowską przeprowadzona 8 września 2016 roku.

16 Emilia Zimnica-Kuzioła, Festiwale teatralne w Eodzi ..., s. 124. 
Dotknij teatru!, doskonale rozumieją podobne procedury i ceremoniały, a wysyłanie maili ułatwiających rezerwację miejsc jest dla nich nawet radosną formą corocznego rytuału. Ale chyba jednak nie o to chodzi, by przekonać przekonanych, lecz by z roku na rok zyskiwać nowych odbiorców. Wydaje się, że obecnie brakuje tej spontaniczności i radości, która wyróżniała festiwal jeszcze w 2010 roku. Dzisiaj wszystko musi być zorganizowane i zaplanowane z góry, bez możliwości dopuszczenia niespodzianki i efektu zaskoczenia. Na dobrą sprawę z festiwalu dla wszystkich zrobił się - paradoksalnie - „konserwatywny” ruch, do którego należy awangardowa elita i środowisko teatralne. Osobom na co dzień nieuczestniczącym w kulturze znów odebrano okazję by się do niej przekonać.

Obok integracji łodzian jednym z głównych celów festiwalu było też zjednoczenie środowiska artystycznego, a także swoista fuzja lokalnych placówek kulturalno-oświatowych, które na czas obchodów współdziałają w imię rozwoju idei, by tak rzec, „wszechogarniającej teatralności”. Do wspólnej celebracji włączyć się mogą także teatry szkolne czy amatorskie. Niezwykłą zaletą tego festiwalu jest to, że jednego dnia widz może obcować z wielkimi nazwiskami scen łódzkich, a drugiego - oglądać debiutujący teatr amatorski. DT nie jest także konkursem, tutaj najwięcej wygrywają uczestnicy i Miasto. Nie ma podziałów na lepszych i gorszych, oceny są całkowicie subiektywne i zależą wyłącznie od indywidualnych gustów widzów.

Efekty dla Miasta są naprawdę olbrzymie. Pierwsza rzecz, która zostaje po Dotknij Teatru! to konkretne spektakle i wydarzenia, dokumentacja. Dotyk teatralny, oczywiście dobry, ma to do siebie, że zostawia w człowieku, w duszy jakiś wir. Jeżeli w wielu osobach coś takiego zostało po wydarzeniach Dotknij teatru! to fantastycznie. Najważniejszym jednak efektem akcji jest tworzenie bardzo solidnego, scementowanego środowiska teatralnego, w którym zachodzą kontakty pomiędzy artystami, pomiędzy instytucjami. To, że teatr instytucjonalny otwiera się na teatr offowy, teatr amatorski. Poza tym, zostaje w mieszkańcach miasta świadomość, że my oto tutaj, w Łodzi, świętujemy Dzień Teatru, że jest coś takiego. Świadomość, emocje, kontakty i otwarty proces, który będzie owocował kolejnymi wydarzeniami ${ }^{17}$.

Jak każdy festiwal, ten także potrafi wzbudzić kontrowersje. Wszak nie odbywa się tutaj wstępny casting na spektakle czy akcje społeczne. Do organizatorów wpływają wnioski, które są rozpatrywane na korzyść aplikujących lub zostają odrzucone, ale zamysł propozycji uczestników organizatorzy w rzeczywistości poznają dopiero wówczas, gdy wspólnie z widzami oglądają spektakl na premierze.

17 Rozmowa autorki artykułu z Panią Anną Ciszowską przeprowadzona 8 września 2016 roku. 
Już pierwsza edycja zaznaczyła się w historii Łodzi dosyć niecodzienną akcją, bowiem w czasie głównych uroczystości Dnia Teatru, odbywających się, jak wspomniałam, w centrum miasta przy pomniku Leona Schillera, jedna z grup alternatywnych (Teatr Art. 51) namawiała przechodniów do podpisania petycji i zrzeczenia się swoich narządów płciowych na rzecz poprawy stosunków międzyludzkich ${ }^{18}$. Organizatorów nie przerażają tego typu śmiałe i prowokacyjne akcje próbujące obudzić w widzu krytycyzm i wrażliwość społeczną. Anna Ciszowska uważa je wręcz za błogosławieństwo, ponieważ projekt artystyczny powstający $\mathrm{w}$ atmosferze pełnych pasji dyskusji czy sporów nabiera energii, dynamicznie się kształtuje, a tym samym rozwija swój potencjał i osiąga optymalną dla siebie formę. Twórczyni koncepcji i strategii Dotknij Teatru! za zjawisko w pełni naturalne i pożądane uważa fakt, że każdy akt artystyczny pokazywany szerszej publiczności poddawany jest jej (krytycznej) ocenie i że nie zawsze odbiorcy czują się usatysfakcjonowani tym, w czym uczestniczą. Bez względu jednak na charakter oceny, każde takie spotkanie niesie za sobą unikalne doświadczenie i cenną lekcję na przyszłość - ważną dla obydwóch stron takiego artystycznego zgromadzenia.

Na przestrzeni lat okazało się, że nie tylko Łódź chce „podotykać” teatru. Przez siedem lat festiwal rozrósł się aż na około 60 miast partnerskich. Łódzka idea prężnie rozwijająca się poza Łodzią? Brzmi znakomicie! Chyba lepszej promocji miasta nie można sobie wyobrazić. Powoli zaczęliśmy się pozbywać naszego „tódzkiego kompleksu” - wiecznego pozostawania w cieniu Stolicy. W wywiadzie przeprowadzonym przez Monikę Wąsik Ciszowska mówi:

Okazało się, że artyści teatru potrzebowali swojego święta. My przetarliśmy szlaki, pokazaliśmy, że można to zrobić, że ta formula się sprawdza. Może trochę zadziwiliśmy inne miasta. Podczas spotkań z koordynatorami z innych miast często słyszeliśmy zdziwienie jak to możliwe, że udało się nam zjednoczyć środowisko i stworzyć wspólnie coś w rodzaju komórki organizacyjnej, będącej w stanie zdobywać pieniądze na ten projekt? W żadnym innym mieście nie udało się tego zrobić. Być może więc zaraziliśmy inne ośrodki naszą pasją. Pamiętam jeszcze te pierwsze spotkania z koordynatorami, gdy przyjmowaliśmy ich w Łodzi obiadem, cieplym słowem i taką naszą gorączką tego opowiadania o projekcie. Bez wątpienia jednak kluczową rolę odegrał także Instytut Teatralny. Nie wiem, jak potoczyłyby się losy Dotknij Teatru, gdyby nie autorytet Instytutu i wsparcie Macieja Nowaka, widzącego potencjał w tej akcji. Pamiętam pierwsze spotkanie z ówczesnym dyrektorem Instytutu. Razem z Konradem Dworakowskim pojechaliśmy do Warszawy i witając

18 Zob. Joanna Rybus, Dzień Teatru świętowali w deszczu, „Gazeta Wyborcza - Łódź” (28 marca 2010), https://lodz.wyborcza.pl/lodz/7,35135,7710280,dzienteatru-swietowali-w-deszczu.html (dostęp: 3.09.2021). 
się z Maciejem Nowakiem, powiedziałam: „Dzień dobry. Mam takie marzenie, żeby Dzień Teatru był jak akcja Owsiaka”, i wtedy Maciej Nowak odpowiedział: „Mam to samo marzenie". Wiedziałam więc, że uda się nam porozumieć. Ten rodzaj romantycznego myślenia chyba został podjęty ${ }^{19}$.

I faktycznie - to porównanie okazuje się trafne. Akcja nie tylko odbywa się $\mathrm{w}$ kraju z nieprawdopodobnym rozmachem, ale też niesie ze sobą wiele pozytywnych skojarzeń i jest wszędzie mile widziana. Tylko czy obejmowanie swoją uwagą działań aż tylu partnerów nie przekłada się na zaniedbywanie łódzkiej części festiwalu? Na moje prowokacyjne pytanie o „kradzież” naszego festiwalu Anna Ciszowska ze spokojem odpowiada:

Nie, nikt nam nie skradł i to byłoby strasznie prowincjonalne, gdybyśmy trzymali patent na obchodzenie Dnia Teatru tylko dla Łodzi. To byłoby jakieś absurdalne! Nie skradł nam, bo też nie może Polska, i z tym się zmaga, urządzić Dotknij Teatru! tak, jak my tutaj, w Łodzi. My tak naprawdę organizujemy akcję luksusowo. Mam na myśli komfort finansowy. Możemy zamówić czy zaproponować artystom organizacje wydarzeń specjalnie dedykowanych na Dzień Teatru. Natomiast Polska takich możliwości wciąż nie ma. Nie ma tam jakiegoś centralnego sposobu finansowania, więc ze środków własnych projektodawcy zgłaszają się do akcji, przez co te wydarzenia, które są zgłaszane do ogólnopolskiej akcji nie są w żaden sposób nadzorowane ideologicznie. To powoduje, że są tam też „złe dotyki”, które chcielibyśmy wyeliminować. My tutaj, w Łodzi, staramy się pilnować, żeby nasze „dotyki teatralne” były wartościowe. W Polsce nie mamy na to żadnego wpływu ${ }^{20}$.

W innych miastach warsztaty teatralne rozszerzone są na różne dziedziny, takie jak: krytyka teatralna, produkcja, warsztaty plastyczne czy muzyczne, wykłady. W warszawskiej wersji festiwalu możemy zobaczyć spektakle, które są znane z wcześniejszego repertuaru, a także premiery. Pokazują się tu w swoich szkolnych spektaklach studenci Akademii Teatralnej, a także np. znany Teatr $21^{21}$, a po

19 Monika Wąsik, Dotknij teatru...

20 Rozmowa autorki artykułu z Panią Anną Ciszowską przeprowadzona 8 września 2016 roku.

21 „Teatr 21 zrodził się w 2005 roku z warsztatów w Zespole Społecznych Szkół Specjalnych »Dać Szansę « w Warszawie. Aktorami są przede wszystkim uczniowie oraz absolwenci szkoły - osoby z zespołem Downa i autyzmem. Ich dawna zabawa w teatr zmieniła się w pracę, za którą otrzymują wynagrodzenie. Spektakle Teatru 21 można było oglądać w warszawskich teatrach (Dramatyczny, Studio, Powszechny, Nowy, Baj, Soho), Muzeum Historii Żydów Polskich POLIN oraz Instytucie Teatralnym im. Zbigniewa 
kilku spektaklach odbywają się spotkania z twórcami i aktorami. Wśród ofert kulturalnych znajdują się wydarzenia przeznaczone specjalnie dla dzieci, dla całych rodzin czy dla seniorów. W Wielkopolsce natomiast można było np. zjeść kolację $\mathrm{z}$ artystami i pomóc przy... odkurzaniu kurtyny teatralnej.

Wiele wydarzeń przygotowanych specjalnie na łódzki festiwal ma swoją artystyczną kontynuację i zyskuje duże, także ogólnopolskie uznanie. Przykładem może być czytanie performatywne sztuki Katarzyna Kobro. Polski sen wg dramatu Kobro Małgorzaty Sikorskiej-Miszczuk, w reżyserii Iwony Siekierzyńskiej, które odbyło się w Teatrze Nowym im. Kazimierza Dejmka 30 marca 2014 roku. Przychylny odbiór tego wydarzenia wpłynął na kształt realizacji spektaklu, który został pokazany jako prapremiera dramatu (22 X 2014) w trakcie innego łódzkiego festiwalu - Awangarda i socrealizm, upamiętniającego 65. rocznicę powstania Teatru Nowego. Spektakl wyróżniono m.in. Nadzwyczajną Złotą Maską (nagroda łódzkich recenzentów teatralnych) w sezonie $2014 / 2015$ i nadal jest grany $z$ wielkim powodzeniem ${ }^{22}$. Także inne przedstawienia przygotowane $\mathrm{w}$ ramach DT po zakończeniu festiwalu weszły do stałego repertuaru scen Łodzi i województwa łódzkiego. Podróż do wnętrza sceny (2012) i Savannah Bay (2013), obydwa w reżyserii Anny Ciszowskiej, oraz Melancholia/Violetta Villas (2015) w reżyserii Tomasza Wygody grane były w Teatrze Nowym im. Kazimierza Dejmka w Łodzi. Wyreżyserowane przez Tomasza Rodowicza spektakle MUZG (2014) oraz Szczelina (2016) systematycznie pokazywane są w Fabryce Sztuki w Łodzi, czyli na scenie twórców widowiska - Stowarzyszenia Teatralnego CHOREA. Obydwa często prezentowane są także w całej Polsce, a Szczelina została laureatem Złotej Maski w 2016 roku. Przedstawienie Studia Saturator Witkacy? - PROFANACJA (2014) w reżyserii Maszy Boguckiej weszło do stałych propozycji Akademickiego Ośrodka Inicja-

Raszewskiego, który jest głównym miejscem aktywności zespołu. Grupa występowała również na festiwalach w kraju (Wrocław, Poznań, Węgajty, Gdańsk, Kalisz, Łódź, Kielce, Białystok, Pszczyna, Lublin) i za granicą (Praga, Neratov, Berlin, Helsinki, Freiburg). Z Teatrem 21 współpracują artyści, edukatorzy i badacze działający na co dzień w instytucjach kultury w całej Polsce. Grupę prowadzi Justyna Sobczyk", strona internetowa Teatru21, http://teatr21.pl/pl/o-nas (dostęp: 10.03.2017).

22 Zob.: Łódź. Sikorska-Miszczuk o Kobro w „Dotknij Teatru”, informacja na stronie portalu e-teatr.pl zawiera też tekst Izabelli Adamczewskiej: Kobro w trójkącie rodzinnym. Wywiad $z$ autorka dramatu, „Gazeta Wyborcza - Łódź” (27 marca 2014), http:// www.e-teatr.pl/pl/artykuly/180019.html?josso assertion id=6D63BA19BB18CFF7 (dostęp: 6.06.2016); Monika Wąsik, Ponad ludzk̄ą miarę? (Po premierze), „Teatr” 2015, nr 1, http://www.teatr-pismo.pl/po-premierze/1024/ponad_ludzka_miare/ (dostęp: 6.06.2016); strona Teatru Nowego im. Kazimierza Dejmka w Eodzi, http://www.nowy. $\mathrm{pl} /$ item/spektakle/article/Kobro/lang/pl (dostęp: 6.06.2016). 
tyw Artystycznych, zaś spektakl A Wersja (2015), stworzony przez Teatr Art. 51 , prezentowany był na scenach Miejskiego Ośrodka Kultury w Zgierzu, w Teatrze Szwalnia, a także na ogólnopolskich festiwalach teatralnych, na których zdobywał nagrody. Podobnie spektakle: Spadając (2015), Wieczór Tischnerowski (2016) oraz Jesteśmy (2016) - wszystkie trzy w reżyserii Marcina Brzozowskiego, przygotowane przez Teatr Szwalnia/Stowarzyszenie Targowa 62 - grane są nadal w rodzimym teatrze. Przedstawienia Tajemnice kwiatu paproci (2015) w reżyserii Przemysława Jaszczaka oraz Zanikam, stworzone przez Katarzynę Dąbkowską-Kułacz, weszły do repertuaru Teatru Zamiast, drugi z nich zdobył także Złotą Maskę. To tylko kilka przykładów „pofestiwalowych karier” inicjowanych tu przedsięwzięć. A trzeba by wspomnieć także o ważnych - zarówno lokalnych, jak i ogólnopolskich - nagrodach, których laureatami było grono prezentujących się na DT aktorów.

Taki obraz rozwoju akcji Dotknij Teatru! wskazuje na wielką (i skuteczną) troskę organizatorów o rzeczywistą solidarność, integrację i aktywizację łódzkich środowisk kulturalno-oświatowych, w tym przede wszystkim teatralnych, a także o kreowanie atrakcyjnego wizerunku Miasta jako nowoczesnego, kreatywnego centrum oryginalnych inicjatyw artystycznych ${ }^{23}$.

Łódzka edycja DT nie stara się budować swoich sukcesów i popularności przez przypisywanie do swojej marki wizerunków medialnych gwiazd, stroni od promowania się przez znane nazwiska.

Nie mamy w nas takiego myślenia, że znane nazwisko jest gwarantem jakości artystycznej. Poza tym nie sądzę, żeby nasi artyści łódzcy byli gorsi w projektowaniu wydarzeń artystycznych niż artyści warszawscy, którzy „mają nazwisko”. To, że ktoś ma promocję to nie znaczy, że za nim stoi wartość. Po drugie, jeżeli mamy ograniczone środki finansowe, to staramy się je wydać na środowisko łódzkie. Natomiast organizacja finansowa tego projektu trochę nam nie pozwala sprowadzać wydarzeń wielkoformatowych. Może się to zmieni, ale też są inne festiwale od organizowania podobnych rzeczy 24 .

23 Informacje dotyczące festiwalu Dotknij Teatru! zostały zaczerpnięte ze źródeł prasowych oraz $\mathrm{z}$ dokumentu: DT Wydarzenia. Nagrody/Sukcesy artystyczne 2010-2015, zbiory prywatne Anny Ciszowskiej. [Por też: Dotknij Teatru. Łódzkie obchody Międzynarodowego Dnia Teatru 2010-2017 [informator], http:// dotknijteatru.pl/wp-content/uploads/2018/03/\%C5\%81\%C3\%B3dzkie-obchodyMi\%C4\%99dzynarodowego-Dnia-Teatru.pdf (dostęp: 3.04.2018) - przyp. red.]

24 Rozmowa autorki artykułu z Panią Anną Ciszowską przeprowadzona 8 września 2016 roku. 
Okazuje się zatem, że organizatorzy wcale nie mają poczucia niższości wobec animatorów festiwalu z tych miast, które mają swoje teatralne sławy, znane z pierwszych stron gazet. Działania odbywają się w Łodzi, a więc lokalni twórcy mogą liczyć na wsparcie i mogą spać spokojnie, ponieważ na pewno nie zostaną odsunięci na boczny tor przez pojawienie się stołecznych celebrytów. Jednak niektóre rozwiązania praktyczne warto by przejąć od innych ośrodków. W programach wielu spośród organizatorów festiwalu nadal można doszukiwać się na przykład wydarzeń przygotowywanych $\mathrm{z}$ „przymrużeniem oka” czy spontanicznych akcji angażujących mieszkańców do współtworzenia polskich obchodów Międzynarodowego Dnia Teatru. Takich akcji niestety u nas ubywa.

A jednak w Łodzi corocznie z determinacją walczy się o widza, za każdym razem bowiem trzeba pozyskać nową grupę odbiorczą.

Co roku wchodzi w życie społeczne nowa grupa: czy to nastolatków, czy też dzieciaków, która staje się naszym potencjalnym odbiorcą teatru. Za każdym razem trzeba podejmować nową próbę rozkochania tych ludzi w teatrze. Nawet jeżeli ktoś jest już teatrem zainteresowany, to trzeba pielęgnować jego zainteresowanie. Tak jak z ogrodem - jeśli wszystko się zasadzi, to i tak nie zwalnia nas to z tego, żeby pielęgnować rośliny 25 .

Wysiłek się opłaca, bo z festiwalu na festiwal notowany jest wzrost widowni. Statystyki rejestrujące łódzkich odbiorców Dotknij Teatru! wahają się między 10 a 14 tysiącami widzów. Czy wszystkich uda się zadowolić? Chyba nie ma na to nadziei, ale organizatorzy zawsze dostają tzw. feedback od uczestników. Z raportu ewaluacyjnego z 2012 roku wynika, że 96\% osób jest zadowolonych z udziału w projekcie, około $90 \%$ zdobyło nową wiedzę i umiejętności, a $81 \%$ zadeklarowało ponowne wykorzystanie wiedzy i umiejętności nabytych podczas udziału w projekcie ${ }^{26}$. Statystyki wypadają zdecydowanie na korzyść festiwalu, pewne wątpliwości budzą jednak kryteria i sposoby wyboru osób, które są poddane badaniu, oraz moment wypełniania przez nie kwestionariusza. Przyznam szczerze, że wielokrotnie uczestniczyłam $\mathrm{w}$ DT - i to nie tylko w jednym czy dwóch wydarzeniach w czasie jednej edycji - a takiej ankiety nie dostałam nigdy. Nie spostrzegłam także, by były one umieszczone w jakimś widocznym miejscu, z którego widz, wychodząc ze spektaklu czy warsztatu, mógłby je wziąć

25 Ibidem.

26 Dane na podstawie dokumentu: Raport ewaluacyjny projektu DOTKNIJ TEATRU - Łódzkie Obchody Międzynarodowego Dnia Teatru w ramach Programu MKiDN Edukacja Teatralna z archiwum Teatru Nowego im. Kazimierza Dejmka w Łodzi. 
i swobodnie wypełnić. Zastanawia mnie zatem, skąd biorą się takie precyzyjne dane? Jak zostały przeprowadzone badania socjologiczne i frekwencyjne?

Kolejna edycja festiwalu, przypadająca na rok 2017, musi niespodziewanie zmóc się z nowymi kłopotami organizacyjnymi: Teatr Nowy im. Kazimierza Dejmka zrezygnował z sygnowania akcji swoim imieniem i autorytetem. Wymówką dotychczasowego organizatora i usprawiedliwieniem jego rezygnacji $\mathrm{z}$ udziału $\mathrm{w}$ festiwalu miały stać się wielkie koszty, jakie teatr ponosił przy jego organizacji. Jednak ze wszelkich dokumentów, do których udało mi się dotrzeć, wynika, że Dotknij Teatru! było dofinansowywane - i to znaczącą kwotą - przede wszystkim przez Miasto. Teraz funkcję inicjatora i koordynatora zdarzeń przejmuje Poleski Ośrodek Sztuki w Łodzi ${ }^{27}$. Jakie będą owoce tej współpracy? Wiadomo, że duży teatr miejski ma większe możliwości pozyskania partnerów i sponsorów niż ośrodek sztuki, nawet prężnie działający. Dzisiaj nie mówi się jednak o stracie, ale o nowym etapie, w który wkracza festiwal. Anna Ciszowska zapytana o dalsze plany czy marzenia związane $\mathrm{z}$ festiwalem odpowiada, że jej jedynym marzeniem jest to, żeby festiwal przetrwał, żeby przetrwała sama idea świętowania Dnia Teatru. I tego właśnie przede wszystkim życzę temu festiwalowi (a także sobie). Może jego reorganizacja - paradoksalnie - uzmysłowi twórcom potrzebę sięgnięcia po nowe, jeszcze ciekawsze niż dotychczasowe środki ekspresji? Może też poszerzy ofertę partycypacji łodzian w tak ważnym i radosnym święcie? Chciałabym w to wierzyć! Optymizmem napawa zdobyta przez Dotknij Teatru! w 2016 roku Nadzwyczajna Złota Maska. Jak czytamy w uzasadnieniu, przyznana za: „[...] wykreowanie w czasach marketingowej iluzji prawdziwie kulturotwórczego zjawiska, które otwiera nowego odbiorcę na to, co w teatrze autentyczne, uczy społecznej empatii i inicjuje rozmowę na temat gatunkowych granic sztuki” 28 . Oby tak pomyślane „kulturotwórcze zjawisko” mogło trwać i pomnażać dobroczynne rezultaty swojego istnienia! Nie da się go bowiem zastąpić żadnym - choćby najefektowniejszym i sponsorowanym bez ograniczen - festiwalem o ustalonym trybie i przewidywalnym sposobie oddziaływania na dobrze zorganizowaną i niewzruszoną w swych estetycznych i towarzyskich wyborach publiczność.

Anna Ciszowska optymistycznie patrzy na losy festiwalu w roku 2017, w którym to tematem DT będą PRZEKROCZENIA, więc może artyści po raz kolejny

27 [Obecnie koordynatorem akcji Dotknij Teatru! jest Akademicki Ośrodek Inicjatyw Artystycznych w Łodzi, którego dyrektorką, od czerwca 2019 roku, jest Anna Ciszowska - przyp. red.]

28 Zob. Łukasz Kaczyński, Złote Maski za sezon 2015/16. Recenzenci nagrodzili twórców teatralnych, „Dziennik Łódzki”, http://www.dzienniklodzki.pl/kultura/ teatr/a/zlote-maski-za-sezon-20152016-recenzenci-nagrodzili-tworcow-teatralnychzdjecia,10742312/ (dostęp: 10.09.2016). 
przekroczą progi instytucji i wyjdą do mieszkańców, tak, jak to było dawniej? Mocno wierzę, że pragnienie „dotykania teatru” przez łodzian nigdy nie zmaleje i będzie ożywczym tlenem dla (obecnie hospitalizującego się po niespodziewanej kontuzji) festiwalu.

Chciałabym skierować słowa wdzięczności do Pani Anny Ciszowskiej za poświęcony mi czas, za niezmienną gotowość służenia pomocą $\mathrm{w}$ interpretacji interesujących mnie zjawisk oraz za fascynujące opowieści o akcji Dotknij Teatru!, jak również serdecznie podziękować Panu Rafałowi Ziębie z Teatru Nowego im. Kazimierza Dejmka w Łodzi za życzliwe udostępnienie mi materiałów archiwalnych, które poszerzyły moją wiedzę na temat akcji. Dziękuję!

Katarzyna Mańko

\section{Bibliografia}

Adamczewska Izabela, Kobro $w$ trójkącie rodzinnym. Wywiad z autorka dramatu, „Gazeta Wyborcza - Łódź” (27 marca 2014), http://www.e-teatr.pl/pl/artykuly/180019. html?josso_assertion id=6D63BA19BB18CFF7 (dostęp: 10.09.2016).

Białczewski Marcin, Dotknij Teatru w Łodzi - informacje, wortal: plasterlodzki.pl, http:// www.plasterlodzki.pl/teatr/aktualnoci-teatralne/819-dotknij-teatru-w-odzi-informacje (dostęp: 10.09.2016).

Dench Judi, Orędzie na Międzynarodowy Dzień Teatru 2010, cyt. za stroną: http:// www.teatrpolski.wroc.pl/archiwum/2009-2010/oredzie-na-miedzynarodowy-dzien-teatru-2010 (dostęp: 10.09.2016).

Kaczyński Łukasz, Złote Maski za sezon 2015/16. Recenzenci nagrodzili twórców teatralnych, wortal: http://www.dzienniklodzki.pl/kultura/teatr/a/zlote-maski-za-sezon-20152016-recenzenci-nagrodzili-tworcow-teatralnych-zdjecia,10742312/ (dostęp: 10.09.2016).

Kultura jako czynnik rozwoju miasta na przykładzie Łodzi, red. Violetta Krawczyk-Wasilewska, Monika Kucner, Emilia Zimnica-Kuzioła, Wydawnictwo Uniwersytetu Łódzkiego, Łódź, 2012.

Łódź. Sikorska-Miszczuk o Kobro w „Dotknij Teatru”, informacja na stronie wortalu, http:// www.e-teatr.pl/pl/artykuly/180019.html?josso_assertion_id=6D63BA19BB18CFF7 (dostęp: 10.09.2016).

[oma/agz/PAP], Dotknij Teatru! - obchody Międzynarodowego Dnia Teatru od 27 marca, [w:] Kultura i sztuka po 1989 roku, www.dzieje.pl, http://dzieje.pl/kultura-i-sztu- 
ka/dotknij-teatru-obchody-miedzynarodowego-dnia-teatru-od-27-marca (dostęp: 10.09.2016).

Rakowski-Kłos Igor, Łódź przemystów teatralnych, „Gazeta Wyborcza - Łódź” (1 marca 2012), s. 1.

Rybus Joanna, Dzień Teatru świętowali w deszczu, „Gazeta Wyborcza - Łódź” (28 marca 2010), https://lodz.wyborcza.pl/lodz/7,35135,7710280,dzien-teatru-swietowali-w-deszczu.html (dostęp: 3.09.2021).

Wąsik Monika, Dotknij teatru - niech się święci!, wortal: teatralny.pl, http://teatralny.pl/ rozmowy/dotknij-teatru-niech-sie-swieci,1001.html (dostęp: 10.09.2016).

Wąsik Monika, Ponad ludzka miarę? (Po premierze), „Teatr” 2015, nr 1, http://www. teatr-pismo.pl/po-premierze/1024/ponad_ludzka_miare/(dostęp: 10.09.2016).

\section{Netografia}

(dostęp: 10.09.2016)

http://dotknijteatru.pl/

http://teatr21.pl/pl/o-nas

http://www.nowy.pl/item/spektakle/article/Kobro/lang/pl

http://www.nowy.pl/item/teatrplus/article/DotknijTeatru/lang/pl 